\title{
NASHVILLE SWAMP-WARBLER.
}

\author{
+ Helinaia rubricapillea, Wils.
}

\section{PLATE CXIII.-Male and Female.}

I have shot only three or four birds of this species, and these were all that I ever met with. I found them in Louisiana and Kentucky. A few specimens belonging to Mr. Titian Peale of Philadelphia, and which he, with his usual kindness, lent me for a few days, to compare their colouring with my drawings and notes, were the only others that I have seen. It is probable he had procured them in Pennsylvania, although I cannot now recollect if this was really the case.

The flight of this little bird is short, light, and entirely similar to that of the other species of this genus already described. Its food consists of insects and larvæ, which it procures by searching diligently and actively amongst the leaves and buds of low trees. It does not pursue insects on wing. With the exception of a few low, eagerly repeated, creaking notes, I have not heard any sounds from them. While uttering these notes, which are all the species seem to have in lieu of song, the male stands erect and still. I am not aware of its nest having been discovered or described by any naturalist.

The plant on a twig of which two Nashville Warblers are represented, is usually called the swamp spice. It is a low bush, grows in the water, in swampy and muddy ground, and occurs from Georgia to New York. The berries, which are seldom eaten by birds, have little pulp, and consequently a large seed.

Nashville Warbler, Sylvia rubricapilla, Wils. Amer. Orn., vol. iii. p. 120.

Sylvia Rubricapilla, Bonap. Syn., p. 87.

Nashville Warbler, Sylvia rubricapilla, Nutt. Man., vol. i. p. 412.

Nashville W Arbler, Sylvia rubricapilla, Aud. Orn. Biog., vol. i. p. 450.

Bill rather short, slender, tapering, nearly straight, as deep as broad at the base. Nostrils basal, lateral, elliptical, half-closed by a membrane. Head of ordinary size, neck short, body full. Feet of ordinary length, slender; tarsus longer than the middle toe, anteriorly scutellate; toes free, scutellate above; claws slender, compressed, acute, arched.

Adult Male. 
Plumage soft, blended, tufty. Wings short, curved, the first and second quills longest. Tail short, forked, of twelve rounded feathers.

Bill greenish-brown. Iris dark brown. Feet yellowish-green. Head and cheeks brownish-grey, the upper part of the head dark red. A circle of white round the eye. The general colour of the upper parts is brownishgreen, of the under greenish-yellow, brighter on the throat and breast. Inner webs of the wing and tail-feathers dusky, the outer brownish-green, and of the primaries bright yellow.

Length $4 \frac{1}{2}$ inches, extent of wings 7 ; bill along the ridge $\frac{1}{3}$, along the gap $\frac{1}{2} ; \operatorname{tarsus} \frac{3}{4}$.

Adult Female.

The female is much duller; the head and hind-neck dark brownish-grey, tinged with green, the former without the red patch, the under parts more mixed with grey, the sides olivaceous, and the yellow of the wings less pure.

\section{The Swamp Spice.}

Ilex Prinoides, Willd. Sp. Pl., vol. i. p. 709. Pursch, Fl. Amer., vol. i. p. 118.Tetrandria Tetragynia, Linn.-Rhamni, Juss.

Leaves lanceolate, attenuated at the base, slightly serrated; peduncles oneflowered. The leaves of this species are deciduous, the berries bright red.

\section{GENUS V.-MNIOTILTA, Vieill. CREEPING-WARBLER.}

Bill rather long, straight, very slender, nearly as broad as high at the base, much compressed toward the end; upper mandible with the dorsal line very slightly convex, the edges a little inflected toward the end, the notches obsolete, the tip acute; lower mandible with the dorsal line straight, the sides convex, the edges involute, the tip attenuated. General form slender. Feet of moderate length, very slender; tarsus shorter than the middle toe and claw, much compressed, the upper scutella blended; toes rather long, extremely compressed, the first very long, the second shorter than the third, which is adherent at the base, claws rather long, well arched, extremely 


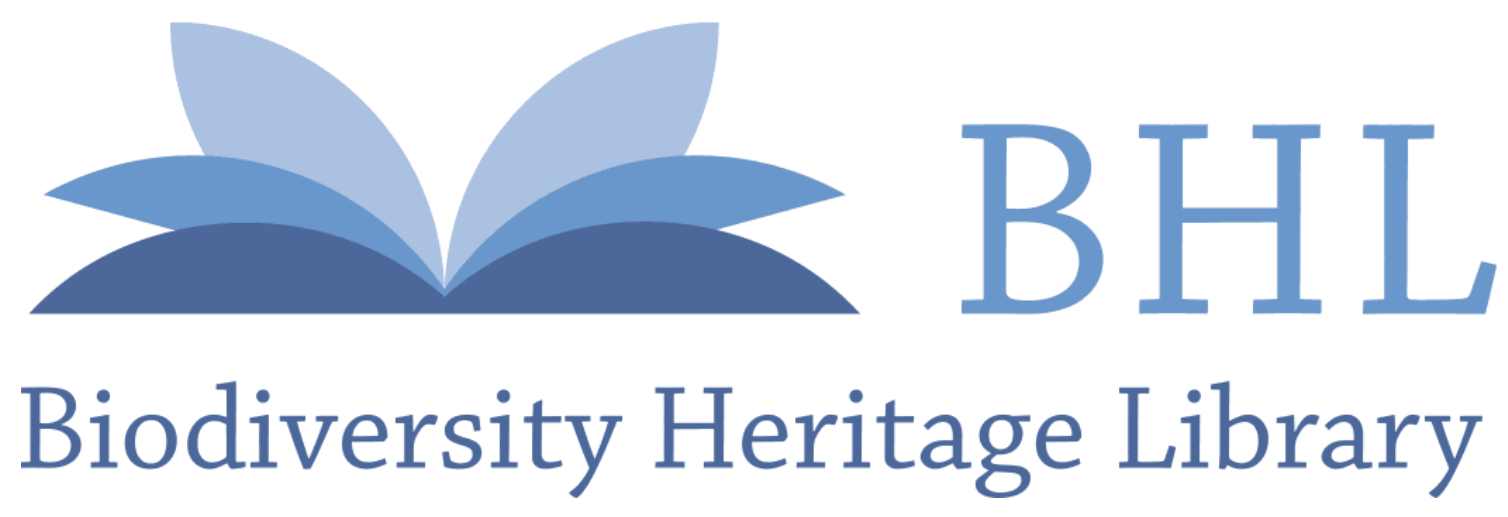

Audubon, John James. 1841. "Nashville Swamp-Warbler, Helinaia rubricapilla, Wils. [PI. 113]." The birds of America : from drawings made in the United States and their territories 2, 103-104. https://doi.org/10.5962/p.319226.

View This Item Online: https://www.biodiversitylibrary.org/item/124834

DOI: https://doi.org/10.5962/p.319226

Permalink: https://www.biodiversitylibrary.org/partpdf/319226

\section{Holding Institution}

Smithsonian Libraries

\section{Sponsored by}

Biodiversity Heritage Library

\section{Copyright \& Reuse}

Copyright Status: NOT_IN_COPYRIGHT

This document was created from content at the Biodiversity Heritage Library, the world's largest open access digital library for biodiversity literature and archives. Visit BHL at https://www.biodiversitylibrary.org. 